Jpn. J. Pharm. Health Care Sci.

ノ - ト 30(5) 330-334 (2004)

\title{
ゲフィチニブにより皮膚病変を来たした一例
}

\author{
前田美希代 ${ }^{* 1,2}$, 石川和宏 ${ }^{1}, G$ ajjar $\mathrm{Amar}^{3}$, 藤井正純 ${ }^{4}$, \\ 若林俊彦 5.6 , 吉田 純 ${ }^{5,6}$, 鍋島俊隆 \\ 名古屋大学医学部附属病院薬剂部 ${ }^{1}$, 同臨床治験管理センター2 \\ St. Jude Children's Research Hospital ${ }^{3}$, 名城病院脳神経外科 ${ }^{4}$ \\ 名古屋大学医学部附属病院脳神経外科 ${ }^{5}$, 同遺伝子再生医療センター ${ }^{6}$
}

\section{Cutaneous Adverse Reactions in a Patient Treated with Gefitinib (Iressa)}

\author{
Mikiyo Maeda*1.2, Kazuhiro Ishikawa', Gajjar Amar', Masazumi Fujii', \\ Toshihiko Wakabayashi ${ }^{5.6}$, Jun Yoshida ${ }^{5,6}$ and Toshitaka Nabeshima ${ }^{1}$ \\ Department of Neuropsychopharmacology and Hospital Pharmacy, \\ Nagoya University Graduate School of Medicine ${ }^{1}$ \\ Center for Clinical Trial and Clinical Research, Nagoya University Hospital ${ }^{2}$ \\ St. Jude Children's Research Hospital ${ }^{3}$ \\ Meijo Hospital, Department of Neurosurgery ${ }^{4}$ \\ Department of Neurosurgery, Nagoya University Graduate School of Medicine ${ }^{5}$ and \\ Center for Genetic and Regenerative Medicine, Nagoya University Hospital ${ }^{6}$
}

$\left[\begin{array}{l}\text { Received November 8, } 2003 \\ \text { Accepted February 25, } 2004\end{array}\right]$

We report on the cutaneous adverse reactions of gefitinib (Iressa), an orally active, selective epidermal growth factor (EGF) receptor tyrosine kinase inhibitor that blocks signal transduction pathways, in a 19-year-old woman with recurrent malignant glioma. When treated daily with $250 \mathrm{mg}$ gefitinib (p.o), the patient developed severe itching (Grade 2) and seborrheia (Grade 2) in the scalp, and acneiform eruption on the face (Grade 1) and upper limbs (Grade 1). The application of fluocinonide lotion to her scalp did not improve the symptoms, but the antihistaminic ebastine was effective. These cutaneous adverse reactions result from of gefitinib's direct interference with EGF receptor signaling in the skin and further studies should be conducted to elucidate the mechanisms by which they occur.

Key words — gefitinib (Iressa), epidermal growth factor receptor, acneiform eruption, seborrheic eczema, cutaneous adverse reactions

\section{緒 言}

上皮成長因子受容体チロシンキナーゼ(EGFR) 阻害剂 であるゲフィチニブ(イレッサ $\left.{ }^{\circledR}\right)$ は，EGFR からのシグ ナル伝達を阻害することにより抗腫湯作用を有する従来 にない新しい夕イプの薬剂であり，手術不能または再発 非小細胞肺癌を適応症として，わが国において世界で初 めて承認された ${ }^{1-3)}$ 。また本剤の主な副作用には, 発疹, 掻痒症，皮膚乾燥などの皮膚障害や下痢が報告されてい $ろ^{1-4)}$.

脳腫瘍において, EGFR をコードする遺伝子が高レベ
ルで発現し，増幅，欠損および再配列が高頻度に見出さ れており，頻度や悪性度が最も高いグリオーマの最大 $50 \%$ でこのような変化が認められている ${ }^{5)}$.また, EGFR 発現は，脳腫瘍の悪性度および予後と相関することが報 告されている6).

そこでわれわれは，既存の治療が無効となった再発性 悪性グリオーマの患者に対して，ゲフィチニブによる EGFR を標的とした分子標的治療法を実施したところ， その有効性が確認された(石川ら：未投稿データ).さら に，今回，ゲフィチニブの副作用としてざ瘡様発疹，脂 漏性湿疹などの皮膚病変が顕著に認められたため，その 症状について報告する。

1,2,5,6 愛知県名古屋市昭和区鶴舞町65; 65, Tsurumai-cho, Showa-ku, Nagoya-shi, Aichi, 466-8560 Japan 332 North Lauderdale, Memphis, TN 38105 愛知県名古屋市中区三の丸 1-3-1；1-3-1, San-no-maru, Naka-ku, Nagoya-shi, Aichi, 460-0001 Japan 


\section{症例}

患 者：19歳，女性

主 訴：再発性悪性グリオーマ, 左半身麻㽻

既往歴：特記すべきことなし

現病歴：1999年11月に全身性の㾏攣発作にて発症し，右 側頭・後頭葉腫瘍 (悪性グリオーマ) と診断された。4度 にわたる開頭腫瘍摘出術, IFN- $\beta \cdot \mathrm{MCNU}$ (Ranimustine) · 放射線併用療法, ガンマナイフ治療に加え, 化学療法とし て2001年 5〜10月にかけて CBDCA (Carboplatin) + VP16 (Etoposide) 療法を計 3 コース，次いで2002年 $1 \sim 5$ 月 にかけて未承認薬である temozolomide の内服療法を計 5 クール施行したが腫瘍の増大が認められ，生命の危険 が差し迫った状態となった。腫瘍は浸潤性を有してお り，手術による摘出は不可能であった。

併用薬：カルバマゼピン錠 $100 \mathrm{mg} ; 3$ 錠 (分 3 ), イソソ ルビド液； $90 \mathrm{~mL}($ 分 3 ), パンテチン $20 \%$ 散； $2 \mathrm{~g}$ (分 2 )， 酸化マグネシウム；2 $\mathrm{g}$ (分 2 )

現 症: 既存の治療がすべて無効となり, その後実施さ れた未承認薬 temozolomide の内服療法においても，5 クール施行後無効となった。 そこで，畺性グリオーマに EGFR 発現の頻度が高いこと，かつゲフィチニブは従来 の抗腫瘍剂とは作用機序がまったく異なることから，新 規治療法として EGFR を標的としたゲフィチニブによ る治療法を，薬剤師側から主治医に提案した。協議を重 ねた結果，本治療法が唯一残された治療法であると判断 され，実施することとなった。実施に当たり，脳腫瘍に 対して本剂は保険適応外使用となるため, 当院の臨床受 託研究審査委員会 (IRB)の承認を得た。 その後, イン フォームドコンセントを行い，患者から文書による同意 を得た上で，病理学的診断ならびに本治療を実施した。
分子標的治療法の意義を踏まえて，治療前にあらかじめ 手術にて採取された腫瘍片におけるEGFRの発現を免 疫組織染色法にて確認した。

2002年 8 月 12 日より，ゲフィチニブ 1 日当たり $250 \mathrm{mg}$ 内服の連続50日間投与を開始した。内服開始により，ゲ フィチニブの副作用と思われる下痢, 頭皮に掻痒, 発 疹, 顔面と上肢に発疹, 口内炎掞よび脱毛が認められた。 発現時期や期間について，下痢は内服開始後 4 日目に一 時的に認められ, 頭皮の掻痒は12日目から, 頭皮の発疹 (脂漏性湿疹) および顔面の発疹(ざ瘡様発疹) は15日目か ら，上肢の発疹(ざ瘡様発疹) は40日目から認められた。 口内炎は27-35日目で認められ，脱毛については，正確 な発現時期は不明であった (Fig. 1)。また, 副作用の程 度としては, 頭皮の掻痒および脂漏性湿疹がともに Grade 2 であった以外は, すべて Grade 1 と, 非常に軽 度なものであった (Table 1)。主訴である再発性悪性グ リオーマに対しては，ゲフィチニブの投与により神経症 状の改善を認め, 頭部 MRIでも Stable Disease(SD)との 結果を得た。その時までの腫瘍の増大傾向に比べると， ゲフィチニブで腫瘍の抑制効果が期待できると判断さ れ，2002年10月18日より再度50日間のゲフィチニブ連続 投与を開始した。しかし，2002年11月16日より意識障害 が出現し, 頭部 CT 上, 腫瘍の増大傾向を認めたため本 剤の投与は中止となり，2002年12月27日に死亡退院され た。

経 過：顔面，上肢に見られたざ瘡様発疹にはナジフロ キサシンクリームを使用し, 症状は軽快した。ところが, 頭皮の脂漏性湿疹は強い掻痒感を伴っていた。そこで皮 䖉科を受診したところ, 外用ステロイド郕であるフルオ シノニドローションが処方され(処方理由は不明), 氷枕 による頭部の冷却を併用したが，フルオシノニドロー

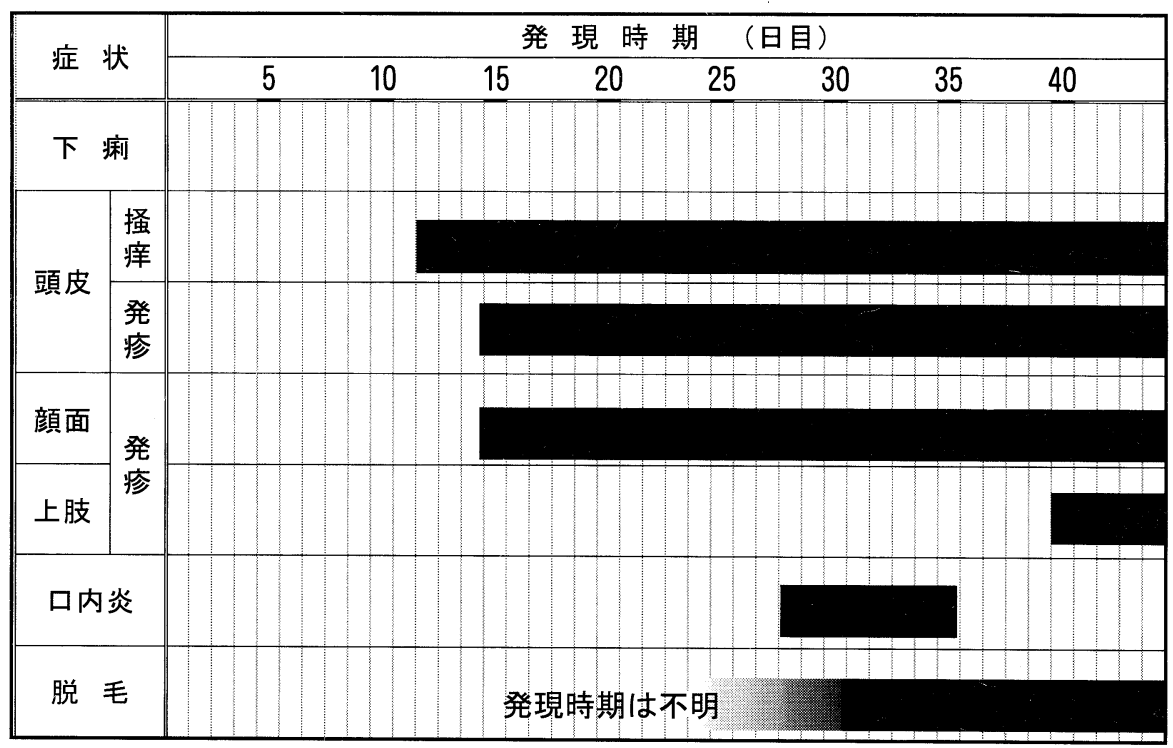

Fig. 1. 副作用発現時期 ·期間 
ションでは塗布後の短時間しか掻痒が治まらず，患者に よるフルオシノニドローションの使用頻度が徐々に高 まった(12-30日目，Fig. 2)。そのため主治医と協議の 上，フルオシノニドのような強力なステロイド剤を頭皮 のような弱い皮膚に継続して使用することは不適当であ ると判断し，フルオシノニドローションの使用を中止し た。しかし，強い掻痒感を取り除き，患者に主訴に対す る治療に専念してもらうために，次にわれわれは，掻痒 感の軽減を目的に抗ヒスタミン剂であるエバスチンの内 服を試みた。その結果, 掻痒感は減少し, 経過観察した ところ，発疹も次第に軽快された(Fig. 2).

\section{考察}

EGFR は，さまざまな癌細胞に発現しており7)，同様 に上皮ケラチノサイトや，皮膚上の他の細胞にも発現し ている ${ }^{8)}$ EGFR シグナルは, 癌細胞では細胞増殖を誘 発し,さらに血管新生や浸潤および転移の充進, アポトー シスの抑制等に関わっている シグナル伝達の選択的阻害剂であり，その作用は, EGFR の細胞内チロシンキナーゼ部位にATPが結合するのを

Table 1. 副作用症状の程度

\begin{tabular}{|c|c|c|}
\hline \multicolumn{2}{|c|}{ 症 状 } & Grade \\
\hline \multicolumn{2}{|c|}{ 下痢 } & 1 \\
\hline \multirow{2}{*}{ 頭 皮 } & 掻 㾕 & 2 \\
\hline & 発 疹 & 2 \\
\hline 顔 面 & \multirow{2}{*}{ 発 疹 } & 1 \\
\hline 上肢 & & 1 \\
\hline \multicolumn{2}{|c|}{ 口内炎 } & 1 \\
\hline \multicolumn{2}{|c|}{ 脱 毛 } & 1 \\
\hline
\end{tabular}

抑制することによるものである。なお，本剂は非小細胞 肺癌のみの適応であるが, 現在では数々の固形癌の治療 において第 II 相，第正相臨床試験が行われている.

ゲフィチニブは，わが国において厚生労働省より 2002 年 7 月に輸入承認を受けた。世界に先駆けて承認を得た こと，さらに発売後の期間が短いことから，国内におけ る臨床試験の結果や症例報告はほとんどなく，そのため 副作用についての詳細に不明な点が多いのが現状であ る。副作用情報が得られるものとして，海外における開 発治験関連の報告 ${ }^{1-3)}$ や インタビューフォーム年があ り，これらによると主な副作用は発疹，下㾥，掻痒症， 皮膚乾燥，嘔気などである。発疹においては，ざ瘡様発 疹や，脂漏性湿疹が報告されている。また，発売後 5 力 月余りで本剤との関連性を否定できない肺障害による死 亡例が報告されており，緊急安全性情報が出され，使用 上の注意が喚起されている.

今回，われわれは，既存の治療法が無効となった再発 性悪性グリオーマの患者に対して，ゲフィチニブの内服 治療を実施した。本症例において，副作用として顔面と 上肢にざ瘡様発疹，頭皮に脂漏性湿疹が認められ，特に 頭皮の脂漏性湿疹においては強い掻痒感を伴っていた。 そのため外用ステロイド剤を使用したが, 発疹の改善や 掻痒感の軽減は十分に得られなかった。 そこで，掻痒感 を緩和するために抗ヒスタミン剤の内服を開始したとこ ろ，掻痒感が軽減された上に発疹もまた軽減された。こ れら一連の経過は, 強い掻痒感のために皮膚へのスク ラッチングの回数が増加し, 発疹はそれによって引き起 こされた細菌性のものである可能性が高く，したがって 発疹の軽快が得られたのは, 抗ヒスタミン剂により掻痒 感が軽減され，スクラッチングの回数が減少したためと 推察される。今回使用した薬剤はエバスチンであるが, 掻痒感を抑える薬剤であればエバスチンでなくても同様

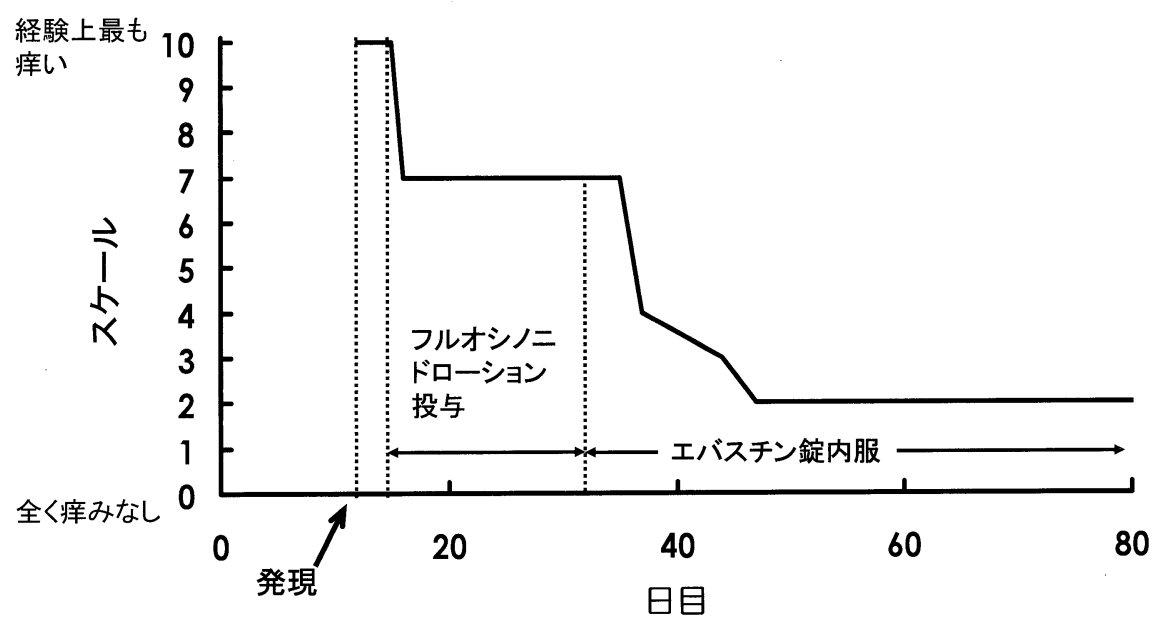

Fig.2. 頭皮の掻痒, 発疹の経過 
な結果が得られたと思われる。また，ゲフィチニブによ り発疹が誘発された他の症例に対して, 今回と同様に抗 ヒスタミン剤が奏功するのかどうかは疑問が残る。しか し，ゲフィチニブを内服する患者の増加が予想される中 で, 本症例での経験によって, 本剤の副作用として生じ る掻痒感に対して，より効果的で迅速な対応をするため に，抗ヒスタミン剤は選択肢の一つになると思われる。 さらに今回, 本症例にとっては主訴に対して他に有効な 治療がなく，ゲフィチニブの内服治療法が残された唯一 の治療法であったからこそ，より快適に治療に専念して もらうために，薬剤師として副作用の軽減に貢献できた ことは有意義なものであったと考える. EGFR 標的療法 の皮膚病変に対する治療の報告はほとんどなく，ゲフィ チニブの投与を受けた数名の患者で毛包炎がみられた症 例報告 ${ }^{10)}$ では，トレチノインクリームの使用とミノサイ クリンの内服を行ったところ症状の緩和が得られたとさ れており, 副作用対策としては各症状に対する対症療法 しかないのが現状である。

本症例において，ゲフィチニブ投与中は皮膚病変を誘 発したり悪化させたりするような他の薬剤は併用してい なかった、ゲフィチニブによる皮膚障害は, 免疫学的に 誘発されるものではなく，表皮や毛包上の EGFR シグ ナル伝達を阻害する結果として現れると考えられてい る10).したがって，このような皮膚障害が生じるのは， 皮膚での機能維持にEGFR が重要な役割を担っている ためと思われる.ゲフィチニブの投与を受けた65例の皮 膚を用いて，本剂投与前と投与中の皮膚生検組織を比較 検討した試験では，その角質層の厚さが投与中の皮膚に おいて優位に薄くなっていたと報告11)されている。この 報告では，角質層が薄くなった患者に対してどのような 治療を行ったかについては触れられていない，角質層が 薄くなった理由として, EGFRが阻害された結果，上皮 ケラチノサイトの分化に変化が生じたためと推察されて いる．この報告から，角質細胞は皮膚のバリアを形成し ていることより，そのバリア機能が落ちると外部から刺 激物質や抗原が侵入しやすくなり, その結果, 炎症反応 が引き起こされると考えられる。したがって，ゲフィチ ニブを投与された皮膚では，角質層のバリア機能が損な われるため, 易感染性や被刺激性が光進し, 発疹や掻痒 が生じやすくなると推察される。

ヒトの皮膚において，EGFRは上皮ケラチノサイト， 外毛根鞘, 皮脂腺に発現している8 . 今回のわれわれの 症例では, 発疹が頭皮, 顔面, 上肢に限局してみられ た。その発疹は毛孔一致性であったこと, さらに皮脂腺 は頭部や上肢に多く存在することから, 本剤の EGFR 阻害作用が毛包や皮脂腺の機能阻害に影響していると考 えられた. EGFRのノックアウトマウスでは, 毛周期に おける成長期から退行期への移行が妨げられ，毛包が破
壊され毛包周囲の細胞浸潤が生じたと報告されてお

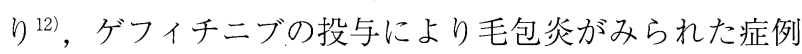
報告 ${ }^{10)}$ では，これらノックアウトマウスで得られた結果 と同様の機序によって皮膚の炎症が発生したのではない かと推察されている。また，これらの報告と同様な発疹 が, 抗 EGFR モノクローナル抗体である IMC-C $225^{13)}$ や, EGFR チロシンキナーゼ阻害剤である OSI $224^{14)}$ でも報告 され，IMC-C225を投与された患者の皮膚生検組織にお いて, 角栓を伴う毛孔閉塞, 毛包破壊, 毛包周囲の細胞 浸潤がみられている3,14)。これらの所見は，EGFRを介 するシグナル伝達が阻害されたため角化細胞の分化が異 常を来たしたためと推察されている15).いずれにしても 未だ詳細な機序は不明であり, 確実な副作用対策はな い.しかし，有用な抗腫瘍剂であるゲフィチニブを用い た治療を行う中で，患者に少しでも快適な生活を送って もらえるよう, 副作用軽減に向けた, すなわち, 対症療 法ではなく副作用根治治療に向けたさらなる研究が期待 される。

薬物治療中の副作用の発現をできる限り低く抑えて治 療を継続していくために, 臨床薬剤師は薬の特性に基づ いた副作用発現機序を正確に理解し, 薬学的見地からよ り適切な副作用対策を行っていくことが重要であると思 われる. 今後, 数々の分子標的治療薬が登場してくると 予想されるが，その一つ一つに対して最大限の治療効果 と最小限の副作用という質の高い治療を実施できるよう に取り組んでいくことが，臨床薬剤師に課せられた今後 の重要な役割である.

\section{引用文献}

1) M. Ranson, L.A. Hammond, D. Ferry, M. Kris, A. Tullo, P.I. Murray, V. Miller, S. Averbush, J. Ochs, C. Morris, A. Feyereislova, H. Swaisland, E.K. Rowinsky, ZD 1839, a selective oral epidermal growth factor receptor-tyrosine kinase inhibitor, is well tolerated and active in patients with solid, malignant tumors : results of phase I trial, J. Clin. Oncol., 20, 2240-2250(2002).

2) R.S. Herbst, A.M. Maddox, M.L. Rothenberg, E.J. Small, E.H. Rubin, J. Rojo, W.K. Hong, H. Swaisland, S.D. Averbuch, J. Ochs, P.M. LoRusso, Selective oral epidermal growth factor receptor tyrosine kinase inhibitor ZD 1839 is generally well tolerated and has activity in non-small cell lung cancer and other solid tumors : results of a phase I trial, J. Clin. Oncol., 20, 38153825(2002).

3) J. Baselga, D. Rischin, M. Ransen, H. Calvert, E. Raymond, D.G. Kieback, S.B. Kaye, L. Gianni, A. Harris, T. Bjork, S.D. Averbuch, A.Feyereislova, H. Swaisland, F. Rojo, J. Albanell, Phase I safety, pharmacokinetic, and pharmacodynamic trial of ZD 1839, a selective oral epidermal growth factor receptor tyrosine kinase inhibi- 
tor, in patients with five selected solid tumor types, $J$. Clin. Oncol., 20, 4292-4302(2002).

4) アストラゼネカ株式会社, 副作用発現状況一覧表, イレッサ®錠250医薬品インタビューフォーム，2829(2002).

5) L. Frederick, X.Y. Wang, G. Fley, C.D. James, Diversity and frequency of epidermal growth factor receptor mutations in human glioblastomas, Cancer Research, 60, 1383-1387(2000).

6) E. Jaros, R.H. Perry, L. Adam, P.J. Kelly, P.J. Crawford, R.M. Kalbag, A.D. Mendelow, R.P. Sengupta, A. D. Pearson, Prognostic implications of p 53 protein, epidermal growth factor receptor, and Ki-67 labelling in brain tumors, Br. J. Cancer, 66, 373-385(1992).

7) S.A. Aaronson, Growth Factors and cancer, Science, 254, 1146-1153(1991).

8) L.B. Nanney, M. Magid, C.M. Stoscheck, L.E. Jr. King, Comparison of epidermal growth factor receptor distribution in normal human epidermis and epidermal appendages, J. Invest. Dermatol., 83, 385-393(1984).

9) W.S. Chen, C.S. Lazar, M. Poenie, R.Y. Tsien, G.N. Gill, M.G. Rosenfeld, Requirement for intrinsic protein tyrosine kinase in the immediate and late actions of the EGF receptor, Nature, 328, 820-823(1987).

10) R.V. Doorn, G. Kirtschig, E. Scheffer, T.J. Stoof, G. Giaccone, Follicular and epidermal alterations in patients treated with ZD 1839 (Iressa) an inhibitor of the epidermal growth factor receptor, Br. J. Dermatol.,
147, 598-601(2002).

11) J. Albanell, F. Rojo, S. Averbuch, A. Feyereislova, J. M. Mascaro, R. Herbst, P. LoRusso, D. Rischin, S. Sauleda, J. Gee, R.I. Nicholson, J. Baselga, Pharmacodynamic studies of the epidermal growth factor receptor inhibitor ZD 1839 in skin from cancer patients : histopathologic and molecular consequences of reseptor inhibiton, J. Clin. Oncol ., 20, 110-124(2002).

12) R. Murillas, F. Larcher, C.J. Conti, M. Santos, A. Ullrich, J.L. Jorcano, Expression of a dominant negative mutant of epidermal growth factor receptor in the epidermis of transgenic mice elicits striking alterations in hair follicle development and skin structure, EMBO J., 14, 5216-5223(1995).

13) K.J. Bunsam, P. Capodieci, R. Motzer, T. Kiehn, D. Phelan, A.C. Halpern, Cutaneous side-effects in cancer patients treated with the antiepidermal growth factor receptor antibody C 225, Br. J. Dermatol., 144, 11691186(2001).

14) A. Kimyai-Asadi, M.H. Jih, Folliculat toxic effects of chimeric anti-epidermal growth factor receptor antibody cetuximab used to treat human solid tumor, Arch. Dermatol., 138, 129-131(2002).

15) D. Peus, L. Hamacher, M.R. Pettelkow, EGF-receptor tyrosine kinase inhibition induces keratinocyte growth arrest and terminal defferntiation, J. Invest. Dermatol., 109, 751-756(1997). 